\title{
REGULAMENTAÇÃO DA ROTULAGEM DOS ALIMENTOS VEGETARIANOS SOB A PERSPECTIVA DO CÓDIGO DE DEFESA DO CONSUMIDOR
}

\author{
VEGETARIAN FOODS LABELING REGULATION UNDER THE PERSPECTIVE OF THE \\ CONSUMER'S PROTECTION CODE \\ NSTRUMENT OF POSITIVE ALLOCATION OF RISKS IN CONTRACTS
}

Fabrício Germano Alves* Marcelo Henrique Lopes Varella ${ }^{* *}$

\begin{abstract}
RESUMO: O presente trabalho trata sobre a rotulagem de alimentos vegetarianos sob a perspectiva do direito à informação dos consumidores. A informação é um direito consagrado pelo Código de Defesa do Consumidor (Lei Federal 8.078/1990), que neste caso específico está relacionado principalmente com a proteção da saúde e o direito de escolha, por isso a importância do seu estudo. Em vista da variedade de produtos e rótulos que existe atualmente, surge a dúvida sobre como os mesmos devem estar dispostos para respeitar o referido direito a informação. A metodologia deste trabalho consiste em uma pesquisa hipotético-dedutiva, realizada com uma abordagem qualitativa e um propósito descritivo, com a finalidade de propor uma avaliação formativa sobre a temática em estudo. Para garantir a efetividade do direito à informação é preciso que os fornecedores utilizem no rótulo dos alimentos vegetarianos uma marca de fácil identificação pelos consumidores.
\end{abstract}

PALAVRAS-CHAVE: Consumidor. Informação. Rotulagem. Alimentos.

SUMÁRIO: Introdução. 1 Vegetarianismo e Direito à Informação. 2 Rotulagem de Produtos: Informação e Regulamentação. 3 Rotulagem Vegetariana no Direito Estrangeiro. 4 Proposição de Regulamentação para a Rotulagem de Produtos Vegetarianos. Considerações Finais. Referências.

\section{INTRODUÇÃO}

A sociedade contemporânea ocidental é caracterizada pela sua pluralidade e liberdade de escolha. O sistema capitalista paradoxalmente estabelece a massificação do consumo de produtos e serviços ao mesmo tempo em que individualiza o consumo a ponto de o indivíduo - com toda sua complexidade psicossocial e econômica - poder se definir e estabelecer seu papel social a partir daquilo que ele consome ou deixa de consumir.

\footnotetext{
* Doutor em Direito pela Universidad del País Vasco (Euskal Herriko Unibersitatea UPV/EHU), Espanha. Professor dos Programas de Pós-Graduação da Universidade Federal do Rio Grande do Norte (UFRN) e da Universidade Potiguar (UNP).

*** Bacharel em Direito pela Universidade Federal do Rio Grande do Norte (UFRN).
} 


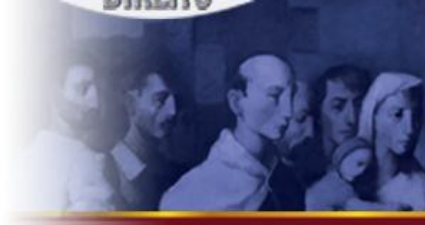

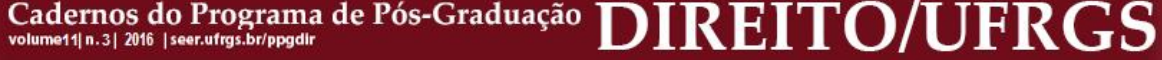

Com o avanço científico e a facilitação do acesso à informação, muitos indivíduos passaram a se definir a partir da sua dieta alimentar. As novas evidências sobre o papel negativo do consumo de animais enquanto alimento para a saúde das pessoas e para o meio ambiente, além da empatia com a causa animal e os direitos dos animais, leva algumas pessoas a excluírem o consumo produtos de origem animal de sua dieta. Estas pessoas são chamadas de maneira geral de vegetarianas.

No ano de 2012, o Conselho Regional de Nutrição do Estado de São Paulo emitiu um Guia Alimentar ${ }^{1}$ sobre dieta vegetariana para adultos, que serve como orientação a nutricionistas com diretrizes para proporcionar uma dieta vegetariana saudável aos pacientes. Nesse documento constam as causas principais que levam o indivíduo a optar pelo vegetarianismo a partir de dados concretos.

O documento cita oito motivos principais que levam o indivíduo a adotar a dieta vegetariana $^{2}$. O primeiro deles é a ética, a partir da percepção de que os animais são seres capazes de possuir sentimentos e sensações. Em seguida, destaca-se a saúde, uma vez que o vegetarianismo, segundo o referido documento, traz benefícios à saúde humana ${ }^{3}$. O meioambiente também se inclui nesse rol, de acordo com a FAO (Food and Agriculture

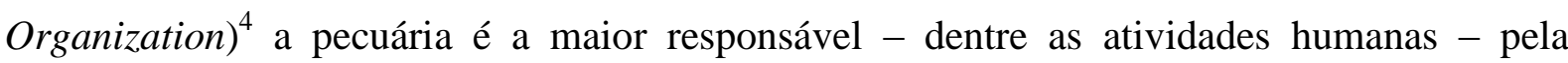
contaminação dos mananciais aquíferos, erosão do solo, além de usar $63 \%$ da terra produtiva do planeta (30\% para a criação de gado e $33 \%$ para cultivo de grãos que alimentam esses animais). As razões espirituais e religiosas também se destacam, já que uma série de cultos e religiões pressupõem a adoção da dieta vegetariana, como o hinduísmo, o budismo, algumas vertentes do espiritismo e o adventismo. Os outros motivos citados no documento são: os motivos familiares, a ioga, a filosofia e simplesmente a não aceitação pelo paladar.

O Direito das Relações de Consumo reconhece através de garantias legais vários grupos humanos com demandas diferentes. Garante aos celíacos (aqueles que não podem ingerir alimentos com glúten) a mensagem “contém glúten” no rótulo dos alimentos e para as

\footnotetext{
${ }^{1}$ SLYWITCH, Eric. Guia alimentar de dietas vegetarianas para adultos. São Paulo: SVB, 2012. Disponível em: <http://www.svb.org.br/livros/guia-alimentar.pdf>. Acesso em: 02 jun. 2016.

${ }^{2}$ Ibid., p. 8.

${ }^{3} \mathrm{O}$ estudo mostra uma série de pesquisas que concluem que as pessoas que adotam a dieta vegetariana, em geral, possuem um nível mais alto de antioxidantes no organismo, um índice de obesidade menor e consequentemente uma melhor saúde cardiovascular. Além de possuírem menor probabilidade de ter doença diverticular, e, em alguns estudos, câncer. As referências dos estudos citados no Guia Alimentar encontram-se na sessão Bibliografia (referências 7-17). Disponível em: 〈http://www.svb.org.br/livros/guia-alimentar.pdf >. p. 11-15; 57. ${ }^{4}$ Disponível em: <http://www.fao.org/newsroom/en/news/2006/1000448/index.html>. Acesso em: 02 jun. 2016.
} 
pessoas com problemas relacionados a colesterol, diabetes, algum tipo de alergia alimentar ou quaisquer outros problemas de saúde, os indicativos nutricionais e os ingredientes no rótulo dos alimentos. Estas garantias são concedidas a partir do conceito de vulnerabilidade do consumidor, que decorre da percepção de que a relação de consumo é uma relação entre partes com forças desiguais: o consumidor e o fornecedor, sendo o primeiro, em regra, a parte mais frágil da relação, e portanto, mais vulnerável. O grupo de consumidores enquanto coletividade que possui uma demanda específica deve receber proteção legal para que seja compensada sua vulnerabilidade perante o fornecedor na relação de consumo.

Em se tratando de bens de consumo alimentares, é possível observar essa proteção claramente nos rótulos dos produtos. Os exemplos são vastos: desde a listagem dos ingredientes, informações nutricionais e aviso sobre componente de origem transgênica no produto, que são informações que servem para todos, até questões mais específicas voltadas para determinados grupos de pessoas, tais como o aviso de que o alimento contém glúten (direcionado principalmente aos celíacos).

Porém, apesar da demanda social existente, o consumidor vegetariano ainda não possui a proteção necessária, pois não existe regulamentação específica para manufatura nem rotulagem de alimentos destinados aos vegetarianos, o que vai de encontro a direitos e princípios previstos no Código de Defesa do Consumidor (CDC) - instituído pela Lei Federal $n^{\circ} 8.078 / 90$-, sobretudo o direito à informação (Art. $6^{\circ}$, III).

Neste sentido, se observou a necessidade de elaboração de um estudo da rotulagem de alimentos, culminando com uma proposta de rotulagem para alimentos vegetarianos, de acordo com o previsto na Lei Federal $n^{\circ} 8.078 / 90$, mais especificamente em seus artigos $4^{\circ}$ (Política Nacional das Relações de Consumo e suas diretrizes), $6^{\circ}$ (direitos básicos do consumidor) e 31 (informação na oferta de produtos e serviços).

O presente texto consiste em uma pesquisa hipotético-dedutiva, realizada com uma abordagem qualitativa e um propósito descritivo, com a finalidade de propor uma avaliação formativa sobre a temática em estudo. Busca-se, portanto, um aprofundamento do direito à informação previsto no Código de Defesa do Consumidor especificamente em relação à demanda dos consumidores vegetarianos. Parte-se de um estudo breve sobre a regulamentação da rotulagem de alimentos no Brasil para finalmente se definir os termos de uma proposição de rotulagem de alimentos vegetarianos, passando pela verificação de experiências internacionais a partir da legislação e ações de Organizações Não- 


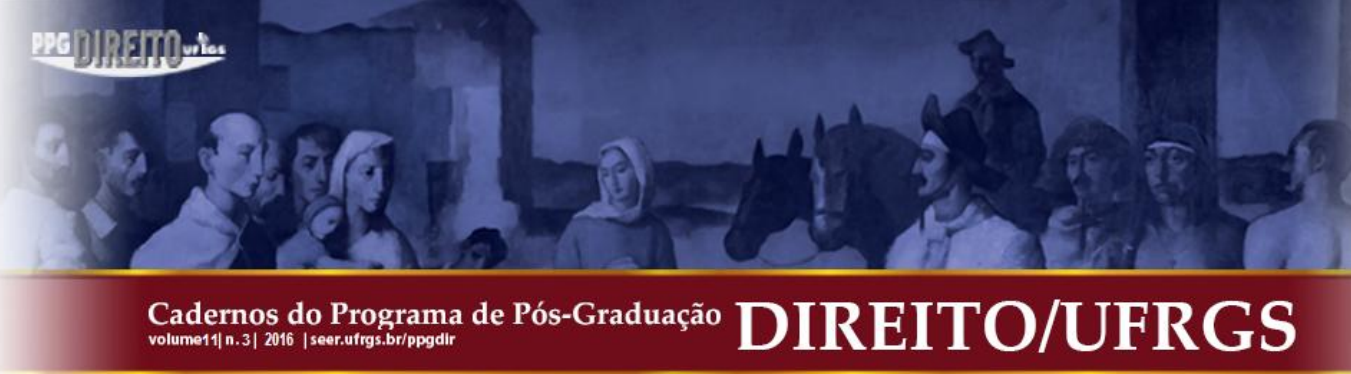

Governamentais (ONGs) que visam garantir a concretização do direito à informação do consumidor vegetariano.

\section{VEGETARIANISMO E DIREITO À INFORMAÇÃO}

Para que seja debatida a rotulagem de alimentos vegetarianos, em primeiro lugar é importante que seja abordada a parte conceitual. Para tanto, a discussão sobre o que caracteriza o vegetarianismo mostra-se necessária na medida em que se trata de um grupo complexo que se ramifica a partir de características e motivações diferentes para a escolha deste tipo de dieta alimentar que constitui um verdadeiro estilo de vida.

No mundo ocidental o vegetarianismo enquanto filosofia fora difundido em princípio por Pitágoras, ainda na Grécia Antiga, que acreditava que todos os seres vivos (homens e demais animais) possuíam uma alma e que, após a morte do corpo físico, reencarnariam. Sendo assim, tornar-se-ia equivalente maltratar um animal não humano a maltratar os homens $^{5}$. Este tipo de dieta era chamado de pitagórica até o ano de 1847 , quando ocorreu em Londres a primeira reunião da Sociedade Vegetariana que oficializou o termo "vegetariano" para o indivíduo que não consome carne animal em sua dieta ${ }^{6}$.

A partir desse momento surgiram conceitualmente muitas variações do estilo de vida e da dieta vegetariana. O médico especialista em nutrologia Eric Slywitch relaciona três tipos principais de dieta vegetariana ${ }^{7}$ : os ovolactovegetarianos, que são aqueles que não consomem carne, mas tem como parte da sua dieta o leite e o ovo; Aqueles que não consomem carne nem ovo, mas alimentam-se de laticínios, que são chamados de lactovegeratianos; e os denominados vegetarianos estritos, que não ingerem, em sua dieta, quaisquer produtos de origem animal. Dentre os estritos ainda é possível se identificar algumas subcategorias, tais como os veganos, que são aqueles que não apenas retiram todos os alimentos de origem animal da sua dieta, mas também rejeitam qualquer bem de consumo que, em seu processo de manufatura, seja oriundo de algum tipo de sofrimento animal, como por exemplo vestimentas de couro, seda ou camurça, cosméticos e produtos de limpeza que sejam testados em animais

\footnotetext{
${ }^{5}$ FELIPE, Sônia T. Antropocentrismo, sencientismo e biocentrismo: perspectivas éticas abolicionistas, bemestaristas e conservadoras e o estatuto de animais não-humanos. Revista Páginas de Filosofia. v. 1, n. 1, jan./jul. 2009, p. $5 . \quad$ Disponível em: $\quad$ https://www.metodista.br/revistas/revistasims/index.php/PF/article/viewFile/864/1168>. Acesso em: 02 jun. 2016.

${ }^{6}$ SLYWITCH, Eric. Virei vegetariano, e agora? 1. ed. São Paulo: Alaúde, 2010, p. 14.

${ }^{7}$ Ibid., p. 15. 
antes de serem colocados no mercado etc; os crudivoros, que se alimentam apenas de alimentos crus ou cozidos em temperatura inferior a $42^{\circ}$, e os frugívoros, que se alimentam apenas de frutas, cereais, legumes e oleaginosas.

Será considerado para efeito deste estudo o termo vegetariano para os ovo-lactovegetarianos e o termo vegano para os vegetarianos estritos e vegans. Estes dois termos serão retomados em tópico futuro possuindo uma importância fundamental para o objetivo do presente texto - a proposição para a rotulagem de alimentos vegetarianos.

As motivações para que se adote o estilo de vida vegetariano em qualquer de suas vertentes são variadas. Desde as recomendações médicas e nutricionais, passando pela comoção com a questão dos maus tratos aos animais, até questões e causas religiosas. Por exemplo, os adventistas do sétimo dia são partidários da dieta vegetariana, assim como os seguidores do budismo, do hinduísmo, hare krishna, sikhismo e algumas vertentes do espiritismo. Verifica-se, portanto, uma demanda que pode ser extensa dentro do mercado de consumo, especialmente dentro do ramo alimentício.

O Código de Defesa do Consumidor é o principal instituto jurídico voltado para regulamentar as relações de consumo. Uma relação de consumo é vinculada a três elementos principais: o elemento subjetivo, o elemento objetivo e o elemento causal ou finalístico ${ }^{8}$. O primeiro abrange os sujeitos da relação de consumo: o consumidor e o fornecedor. O segundo é o produto ou serviço colocado pelo fornecedor no mercado, isto é, o objeto da relação de consumo $^{9}$. O terceiro e último elemento, o causal ou finalístico, deriva da chamada teoria finalista.

A teoria finalista restringe o consumidor àquele que é destinatário final de um produto ou serviço. É o próprio Código de Defesa do Consumidor que consagra essa teoria ao conceituar, em seu artigo $2^{\circ}$, o consumidor como o destinatário final de um produto ou serviço. A destinação final de um produto ou serviço pode ser subdividida em duas categorias: a destinação final fática e a destinação final econômica ${ }^{10}$. A fática permite considerar destinatário final o consumidor que não passa o produto ou serviço adiante, constituindo-se a

\footnotetext{
${ }^{8}$ ALVES, Fabrício Germano. Proteção constitucional do consumidor no âmbito da regulação publicitária. 1. ed. Natal: Espaço Internacional do Livro, 2013, p. 44.

${ }^{9}$ MATOSO, Vanessa de Azevedo. A publicidade de alimentos: uma análise acerca da informação prestada ao consumidor. 2015. Trabalho de Conclusão de Curso (Bacharelado em Direito) - Centro de Ciências Sociais Aplicadas, Universidade Federal do Rio Grande do Norte, p. 13.

${ }^{10}$ TARTUCE, Flávio; NEVES, Daniel Amorim Assumpção. Manual de direito do consumidor: direito material e processual. 3. ed. Rio de Janeiro: Forense: São Paulo: Método, 2014, p. 76.
} 


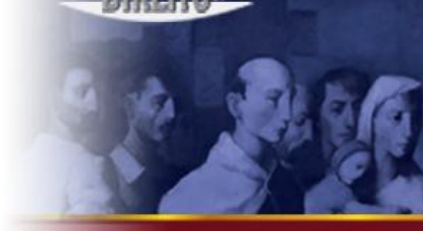

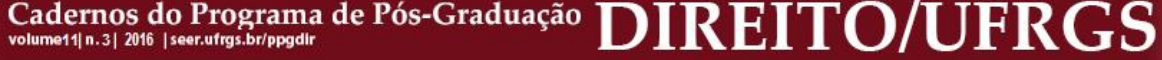

Em uma relação consumerista o fornecedor e o consumidor estão vinculados a direitos

e deveres. É estabelecido, pois, que esta relação de consumo destina-se a satisfação de uma necessidade do consumidor, em posição de vulnerabilidade, que se encontra sem nenhum controle sobre a produção dos bens de consumo que irá adquirir na condição de destinatário final, ficando submetido ao poder e condições determinadas pelos fornecedores ${ }^{14}$. Esta relação de desequilíbrio é atenuada pelo Código a partir de garantias de princípios e direitos ao consumidor em seus artigos $4^{\circ}$ e $6^{\circ}$, com destaque, devido ao propósito deste estudo, para o direito à informação e para a liberdade de escolha.

$\mathrm{O}$ artigo $4^{\circ}$ do $\mathrm{CDC}$, prezando pela transparência e harmonia das relações de consumo elenca oito princípios da Política Nacional das Relações de Consumo ${ }^{15}$. O quarto inciso do referido artigo traz como princípio a educação e a informação de fornecedores e consumidores quanto aos seus direitos e deveres ${ }^{16}$. Ou seja, o Código trata como imperativo e essencial que o consumidor esteja versado quanto aos seus direitos e bem informado acerca dos deveres do fornecedor.

O artigo $6^{\circ}$ elenca os direitos básicos do consumidor decorrentes da relação de consumo. O inciso II do referido artigo assegura a liberdade de escolha a partir da educação do consumidor acerca do produto ou serviço e seu consumo adequado ${ }^{17}$. O terceiro inciso traz como direito básico do consumidor a informação clara acerca dos serviços e produtos, especificando corretamente suas características, quantidade, qualidade, composição, os tributos que incidem sobre os mesmos, bem como os riscos inerentes aos mesmos e o preço.

Portanto, a informação como direito e como princípio da Política Nacional das Relações de Consumo, que se traduz na transparência e harmonia da relação entre consumidor e fornecedor, garantindo a liberdade de escolha, vincula o fornecedor ao dever de prestar informações de maneira cabal sobre os produtos e serviços colocados no mercado ${ }^{18}$.

\footnotetext{
${ }^{14}$ GRINOVER, Ada Pellegrini et al. Código Brasileiro de Defesa do Consumidor: comentado pelos autores do anteprojeto. 8. ed. Rio de Janeiro: Forense Universitária, 2004, p. 32.

${ }^{15}$ Art. $4^{\circ}$. A Política Nacional das Relações de Consumo tem por objetivo o atendimento das necessidades dos consumidores, o respeito à sua dignidade, saúde e segurança, a proteção de seus interesses econômicos, a melhoria da sua qualidade de vida, bem como a transparência e harmonia das relações de consumo, atendidos os seguintes princípios.

${ }^{16}$ Art. $4^{\circ}$, IV - educação e informação de fornecedores e consumidores, quanto aos seus direitos e deveres, com vistas à melhoria do mercado de consumo.

${ }^{17}$ Art. $6^{\circ}$. São direitos básicos do consumidor: [...] II - a educação e divulgação sobre o consumo adequado dos produtos e serviços, asseguradas a liberdade de escolha e a igualdade nas contratações.

18 "Assim, da soma dos princípios, compostos de dois deveres - o da transparência e o da informação -, fica estabelecida a obrigação de o fornecedor dar cabal informação sobre seus produtos e serviços oferecidos e 


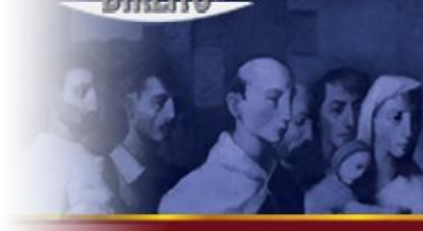

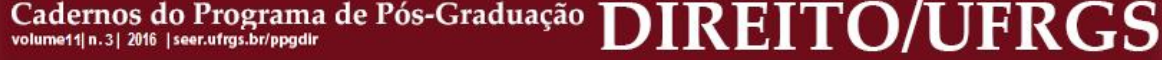

Dentre as maneiras de satisfazer o direito do consumidor à informação correta e adequada acerca do produto, a mais importante é sem dúvida o rótulo, já que este constitui o primeiro elo entre o consumidor e o produto a ser adquirido, especialmente em se tratando de produtos alimentícios ${ }^{19}$. Dessa forma, deve-se investigar onde se encontra a regulamentação dos rótulos, bem como a sua natureza jurídica.

O Decreto-Lei no 986 de 1969, que institui normas básicas sobre alimentos traz no artigo $2^{\circ}$, inciso XII a definição de rótulo como uma identificação através de litografia, impressão, pintura, gravação a fogo ou pressão, sobre qualquer tipo de embalagem de alimento. Esta definição é complementada pelo artigo 31 do Código de Defesa do Consumidor, que determina que "a apresentação dos produtos deva assegurar as informações corretas, claras e precisas, ostensivas e em língua portuguesa" ${ }^{20}$. O Decreto-Lei ainda traz um Capítulo inteiro (Capítulo III) regulamentando a rotulagem de produtos alimentícios.

Quanto à sua natureza, pode-se concluir, segundo o artigo 18, a do Código Brasileiro de Autorregulamentação Publicitária (CBAP), que o rótulo é uma forma de publicidade ${ }^{21}$, portanto é regulamentado como tal, além de ser passível de todas as obrigações decorrentes da relação entre consumidor e fornecedor.

A rotulagem de produtos no Brasil vem evoluindo a partir de uma demanda social pela informação cada vez mais esmiuçada em relação aos bens de consumo alimentícios. Resoluções da ANVISA, neste sentido - como as RDCs $n^{\circ} 26$ e 360 - surgem para a regulamentação de mais informações nos rótulos, como por exemplo, informações nutricionais. Além disso, existem também Leis e Projetos de lei visando que a rotulagem contenha informações essenciais à saúde e ao bem-estar do consumidor, como o PL nº 8194 de 2014 (informação sobre a presença de lactose nos alimentos) e a Lei Federal nº 10.674 de

colocados no mercado, bem como as cláusulas contratuais por ele estipuladas". NUNES, Rizzatto. Curso de Direito do Consumidor. 6. ed. São Paulo: Saraiva, 2011, p. 182.

19 "Desta forma, a rotulagem tem-se revelado uma importante ferramenta na decisão de compra: o rótulo constitui o primeiro elo de ligação ente os produtos e os consumidores. Fornecendo-lhes informação relevante acerca do produto, permite-lhes fazer escolhas conscientes, saudáveis e seguras, em especial àqueles que sofrem de alergia ou intolerância alimentares". ANALÍTICOS, Limites. Doença celíaca: contributo da análise laboratorial para uma dieta isenta de glúten. Especial 2, p. 36.

${ }^{20}$ Art. 31. A oferta e apresentação de produtos ou serviços devem assegurar informações corretas, claras, precisas, ostensivas e em língua portuguesa sobre suas características, qualidades, quantidade, composição, preço, garantia, prazos de validade e origem, entre outros dados, bem como sobre os riscos que apresentam à saúde e segurança dos consumidores.

${ }^{21}$ Art. 18. Para os efeitos deste Código: a. a palavra anúncio é aplicada em seu sentido lato, abrangendo qualquer espécie de publicidade, seja qual for o meio que a veicule. Embalagens, rótulos, folhetos e material de ponto-devenda são, para esse efeito, formas de publicidade. 


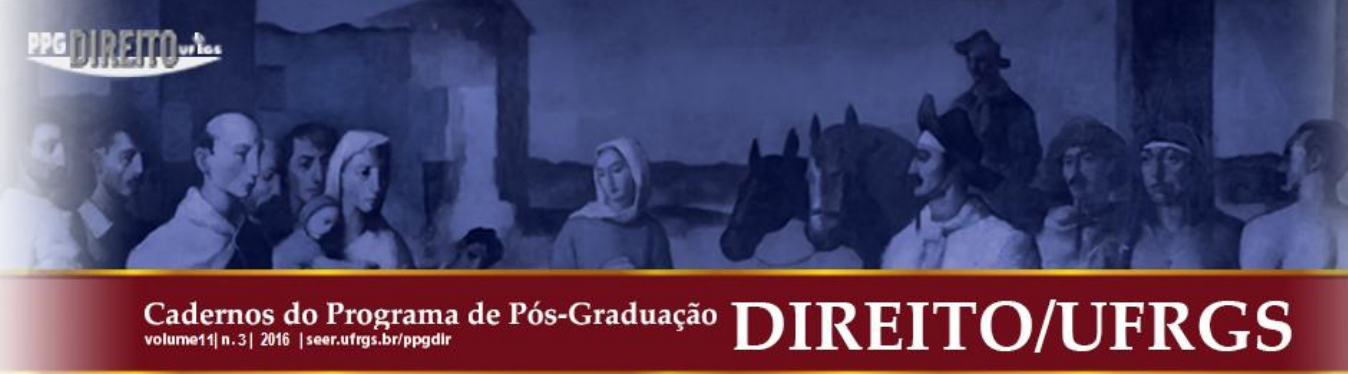

2003 (informação sobre a presença de glúten). Isso demonstra uma adequação aos tempos e à dinâmica das relações humanas, que exigem a regulamentação da rotulagem de alimentos transgênicos, contendo glúten, dentre outras modalidades.

\section{ROTULAGEM DE PRODUTOS: INFORMAÇÃO E REGULAMENTAÇÃO}

Desde o Decreto-Lei no 986/69, a proteção ao consumidor a partir do acesso à informação contida nos rótulos de alimentos no Brasil vem evoluindo gradativamente. $\mathrm{O}$ progresso científico e tecnológico proporcionou um maior conhecimento sobre os benefícios e malefícios de determinados componentes alimentares, além disso, houve também a descoberta de problemas específicos causados por alguns ingredientes presentes em alimentos costumeiramente consumidos que se soma à crescente preocupação e conscientização da população no cuidado da saúde que se traduz em uma reeducação alimentar.

Nesse sentido, o Direito cuidou de aperfeiçoar-se para atender a uma demanda consumerista em mutação - especialmente no que diz respeito aos bens de consumo alimentícios - e garantir novos direitos para o consumidor, resguardando o Princípio da transparência e harmonia nas relações de consumo (Art. $4^{\circ}$, caput, CDC) e o direito do consumidor à informação (Art. $6^{\circ}, \mathrm{III}, \mathrm{CDC}$ ). Esta evolução vem ocorrendo paulatinamente através de recomendações da ANVISA e Leis Complementares, que serão vistas a seguir.

A Agência Nacional de Vigilância Sanitária (ANVISA) foi criada pela Lei Federal $n^{\circ}$ 9.782 de 1999 como autarquia para, entre outras coisas, normatizar, controlar e fiscalizar produtos, substâncias e serviços de interesse para a saúde ${ }^{22}$. Esta Agência exerce seu poder de regulamentação através da chamada RDC (Resolução de Diretoria Colegiada). Ao analisar algumas destas Resoluções é possível observar a evolução na regulamentação da rotulagem dos alimentos, destacando duas Resoluções principais: a RDC n⿳ 360, de 23 de dezembro de 2003 e a RDC no 26 , de 02 de julho de 2015.

A primeira surge para regulamentar a rotulagem nutricional dos alimentos sob a justificativa de que esta contribui para o consumo adequado deles, apresentando uma descrição destinada a informar o consumidor sobre as propriedades nutricionais do alimento

${ }^{22}$ Art. $2^{\circ}$ Compete à União no âmbito do Sistema Nacional de Vigilância Sanitária: [...] III - normatizar, controlar e fiscalizar produtos, substâncias e serviços de interesse para a saúde. 


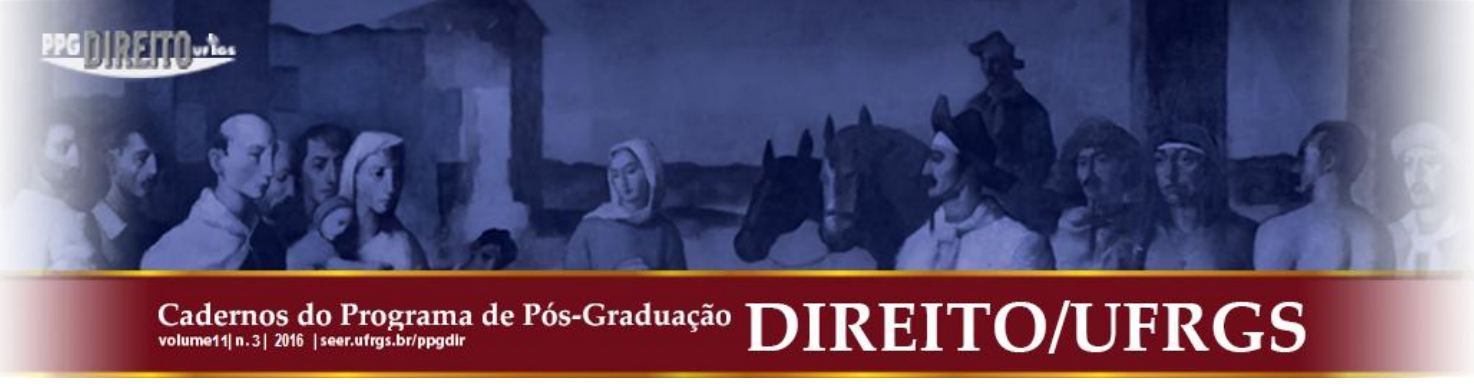

em $\operatorname{voga}^{23}$. Em seu artigo segundo, a Resolução em comento elenca as informações e os nutrientes que devem ser explicitados no rótulo, a saber: valor energético, carboidratos, proteínas, gorduras totais, gorduras saturadas, gorduras trans e sódio ${ }^{24}$.

A segunda visa apresentar os requisitos necessários para a rotulagem obrigatória dos principais alimentos que causam alergia ${ }^{25}$, tendo em vista que existem muitos alimentos no mercado com potencial alergênico para o consumidor sem que o componente capaz de provocar a reação seja essencial à composição do produto. A Resolução recomenda ainda que as advertências alergênicas estejam colocadas após os ingredientes, em caixa-alta, negrito, cor em contraste com o fundo, com altura mínima de $2 \mathrm{~mm}$, e nunca inferior à atura da letra utilizada na lista de ingredientes ${ }^{26}$.

A RDC no 26 elenca em seu anexo a lista de alimentos com potencial alergênico, sendo eles: trigo, centeio, cevada, aveia, crustáceos, ovos, peixes, amendoim, soja, leites de origem animal, amêndoas, avelãs, castanhas-de-caju, castanhas-do-pará, macadâmias, nozes, pecãs, pistaches, pinoli e látex natural. Segundo as recomendações da ANVISA, os fornecedores devem estar adequados a esta Resolução um ano após a sua publicação, ou seja, em meados de 2016.

A mudança não ocorre apenas através da Agência reguladora. A Lei Federal nº 10.674 de 2003 trouxe a obrigação de constar a informação no rótulo do produto alimentício industrializado se o mesmo contém ou não contém glúten ${ }^{27}$. Por glúten, entende-se uma mistura de proteínas presentes em alguns grãos de cereais, tais como o trigo, o centeio, a cevada e a aveia ${ }^{28}$.

A motivação para a existência da mencionada Lei é o crescente número de pessoas diagnosticadas com a doença celíaca, causada pelo consumo de glúten, de natureza autoimune, que se caracteriza pela reação inflamatória crônica no intestino delgado que

\footnotetext{
23 ANVISA Resolução-RDC 360. ANEXO: 2- Definições.

24 Art. $2^{\circ}$. Resolução RDC n⿳0 360, ANVISA.

25 Art. $1^{\circ}$. Resolução RDC n ${ }^{\circ} 26$ ANVISA.

${ }^{26}$ Art. $8^{\circ}$. As advertências exigidas nos artigos $6^{\circ}$ e $7^{\circ}$ desta Resolução devem estar agrupadas imediatamente após ou abaixo da lista de ingredientes e com caracteres legíveis que atendam aos seguintes requisitos de declaração: I - caixa alta; II - negrito; III - cor contrastante com o fundo do rótulo; e IV - altura mínima de 2 mm e nunca inferior à altura de letra utilizada na lista de ingredientes.

27 Art. $1^{\text {o }}$. Todos os alimentos industrializados deverão conter em seu rótulo e bula, obrigatoriamente, as inscrições "contém Glúten" ou "não contém Glúten", conforme o caso.

28 ANALÍTICOS, Limites. Doença celíaca: contributo da análise laboratorial para uma dieta isenta de glúten. Especial 2, p. 36.
} 


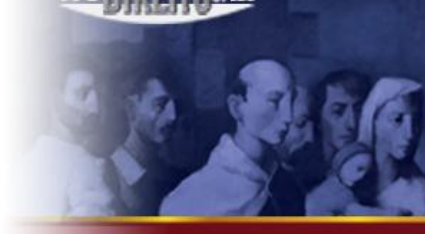

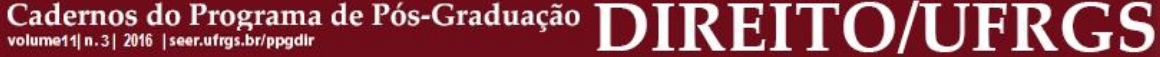

dificulta a absorção de nutrientes ${ }^{29}$. As pessoas nessa condição, portanto, não devem nunca consumir alimentos que contenham o glúten por se tratar de doença crônica e permanente ${ }^{30}$.

Seguindo a mesma linha da Lei Federal $n^{\circ} 10.674 / 03$, existe um Projeto de Lei oriundo do Senado Federal, originalmente conhecido como PLS nº 260 de 2013, que foi repassado para a Câmara dos Deputados como Projeto de Lei no 8.194 de 2014. Este projeto, que foi aprovado na Câmara dos Deputados e aguarda apreciação do Senado Federal sugere um acréscimo ao artigo $19^{31}$ do Decreto-Lei $n^{\circ} 986$ de 1969, já mencionado neste estudo, que trata das normas básicas sobre a comercialização de alimentos. A modificação dar-se-ia no intuito de acrescentar aos rótulos dos alimentos a informação sobre a presença de lactose, assim como existe o aviso sobre a presença do glúten, visando à proteção ao consumidor que é intolerante ou alérgico a este tipo de açúcar presente em laticínios ${ }^{32}$.

Por fim, cabe observar a Lei Federal n 11.105 de 24 de março de 2005, que foi criada com a justificativa de regulamentar os incisos II, IV e V, do $§ 1^{\circ}$ do artigo 225 da Constituição Federal $^{33}$, e ficou conhecida como Lei dos Transgênicos. Esta Lei veio para estabelecer normas de segurança e fiscalização das atividades envolvendo alimentos transgênicos (geneticamente modificados), assim como seus derivados.

Todos os alimentos geneticamente modificados, ou que derivem destes, que se destinem ao consumo humano ou animal, devem possuir em seu rótulo tal informação

\footnotetext{
${ }^{29}$ Ibid., p. 36.

${ }^{30}$ Portaria MS/SAS no 307, de 17 de setembro de 2009. Diário Oficial da União; Poder Executivo, Brasília, DF, 18 set. 2009. Seção I, p. 79-81.

${ }^{31} \mathrm{O}$ artigo 19, atualmente, diz em seu texto: "Os rótulos dos alimentos enriquecidos e dos alimentos dietéticos e de alimentos irradiados deverão trazer a respectiva indicação em caracteres facilmente legíveis. Parágrafo único. A declaração de "Alimento Dietético" deverá ser acompanhada da indicação do tipo de regime a que se destina o produto expresso em linguagem de fácil entendimento". Seria, portanto, acrescido, de acordo com o PL 8194/14: "Art. 19-A. Os rótulos de alimentos que contenham lactose deverão indicar a presença da substância, conforme as disposições do regulamento. Parágrafo único. Os rótulos de alimentos cujo teor original de lactose tenha sido alterado deverão informar o teor de lactose remanescente, conforme as disposições do regulamento".

32 Disponível em: <http://www2.camara.leg.br/camaranoticias/noticias/CONSUMIDOR/481389-PROJETODETERMINA-DIVULGACAO-DE-TEOR-DE-LACTOSE-EM-EMBALAGENS.html>. Acesso em: 02 jun. 2016.

${ }^{33}$ Art. 225. Todos têm direito ao meio ambiente ecologicamente equilibrado, bem de uso comum do povo e essencial à sadia qualidade de vida, impondo-se ao Poder Público e à coletividade o dever de defendê-lo e preservá-lo para as presentes e futuras gerações. $\S 1^{\circ}$ Para assegurar a efetividade desse direito, incumbe ao Poder Público: [...] II - preservar a diversidade e a integridade do patrimônio genético do País e fiscalizar as entidades dedicadas à pesquisa e manipulação de material genético; [...] IV - exigir, na forma da lei, para instalação de obra ou atividade potencialmente causadora de significativa degradação do meio ambiente, estudo prévio de impacto ambiental, a que se dará publicidade; V - controlar a produção, a comercialização e o emprego de técnicas, métodos e substâncias que comportem risco para a vida, a qualidade de vida e o meio ambiente.
}

Cadernos do Programa de Pós-Graduação em Direito PPGDir./UFRgS | Edição Digital | Porto Alegre | Volume XI | Número 3 | 2016 | P. 233-256 


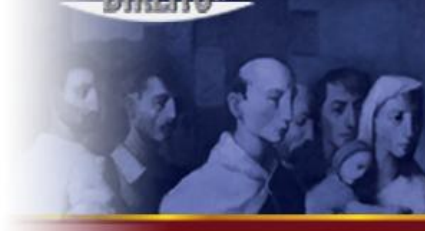

respeitando as normas de proteção ao consumidor. Este direito à informação está contido na Lei Federal no $11.105 / 05$ em seu artigo $40^{34}$.

A regulamentação derivada do mencionado artigo 40 veio na forma da Portaria $n^{\circ}$ 2.658 do Ministério da Justiça, em 22 de dezembro de 2003. No ponto "Apresentação do Símbolo" (ponto 3), a disposição normativa determina que o símbolo deve estar em destaque e em contraste com as cores do rótulo, assegurando a visibilidade, em forma de triângulo equilátero de fundo amarelo (ou branco, em caso de rotulo preto e branco), contendo uma letra $\mathrm{T}$ maiúscula de cor preta, em caixa alta, ocupando no mínimo $0,4 \%$ da área, não sendo inferior a $10,82531 \mathrm{~mm}^{235}$.

A crescente preocupação com o bem-estar e saúde da população direcionada para a alimentação provoca por consequência um maior amparo legal para o consumidor. A alergia alimentar, segundo a ASBAI (Associação Brasileira de Alergia e Imunologia), afeta 6 a 8\% das crianças com menos de três anos de idade e 2 a $3 \%$ dos adultos ${ }^{36}$. A FENACELBRA (Federação Nacional das Associações de Celíacos do Brasil) estima que dois milhões de brasileiros sejam afetados pela alergia ao glúten ${ }^{37}$, enquanto na Medicina sugere-se que $70 \%$ dos brasileiros possuem, em algum grau, intolerância à lactose ${ }^{38}$. Quanto aos alimentos transgênicos, há uma disputa científica em relação aos malefícios causados pelos ingredientes geneticamente modificados. Porém, sabe-se até então certamente apenas que eles são nocivos para o solo e especialmente para o pequeno produtor rural, que se mostra incapaz de competir com a tecnologia das grandes empresas latifundiárias.

\footnotetext{
${ }^{34}$ Art. 40. Os alimentos e ingredientes alimentares destinados ao consumo humano ou animal que contenham ou sejam produzidos a partir de OGM ou derivados deverão conter informação nesse sentido em seus rótulos, conforme regulamento.

${ }^{35}$ Portaria $\mathrm{n}^{\mathbf{0}}$ 2658, de 22 de dezembro de 2003. [...] 3. APRESENTAÇÃO DO SíMBOLO: [...] 3.3 O símbolo deverá constar no painel principal, em destaque e em contraste de cores que assegure a correta visibilidade. $3.4 \mathrm{O}$ triângulo será eqüilátero. $3.5 \mathrm{O}$ padrão cromático do símbolo transgênico, na impressão em policromia, conforme apresentado no item 3.1, deve obedecer às seguintes proporções: 3.5.1 Bordas do triângulo e letra T: 100\% Preto. 3.5.2 Fundo interno do triângulo: 100\% Amarelo. 3.6 A tipologia utilizada para grafia da letra T deverá ser baseada na família de tipos Frutiger, bold, em caixa alta, conforme apresentada no item 3.1. 4. DIMENSÕES MÍNIMAS: 4.1 A área a ser ocupada pelo símbolo transgênico deve representar, no mínimo, 0,4\% (zero vírgula quatro por cento) da área do painel principal, não podendo ser inferior a 10,82531mm2 (ou triângulo com laterais equivalentes a $5 \mathrm{~mm}$ ). $4.2 \mathrm{O}$ símbolo transgênico deverá ser empregado mantendo-se, em toda a sua volta, uma área livre equivalente a, no mínimo, a área da circunferência que circunscreve o triângulo, passando pelos três vértices e com centro no circuncentro. Disponível em: <http://agrobiobrasil.org.br/wpcontent/uploads/2014/01/Portaria-MJ-2658-de-2003-Regulamenta-uso-do-s\%C3\%ADmbolo-dostransg\%C3\%AAnicos.pdf>. Acesso em: 02 jun. 2016.

${ }^{36}$ Disponível em: <http://www.asbai.org.br/secao.asp?s=81\&id=306>. Acesso em: 02 jun. 2016.

${ }^{37}$ Disponível em: <http://www.fenacelbra.com.br/fenacelbra/>. Acesso em: 02 jun. 2016.

${ }^{38}$ Disponível em: <http://drauziovarella.com.br/letras/l/intolerancia-a-lactose/>. Acesso em: 02 jun. 2016.
} 


\section{ROTULAGEM VEGETARIANA NO DIREITO ESTRANGEIRO}

A rotulagem de alimentos vegetarianos ainda é precária em quase todos os lugares do mundo. Apesar de existirem muitas organizações que realizam a rotulagem, em quase nenhum pais do mundo existem leis que protegem o consumidor vegetariano especificamente através de rotulagem.

$\mathrm{Na}$ União Europeia a European Vegetarian Union fornece o chamado V-Label para produtos que não sejam de origem animal, industrializados ou fornecidos em restaurantes. A primeira vez que o símbolo apareceu foi em 1996 na Suíça, e desde então tem se espalhado por diversos países, desde Portugal até a Rússia ${ }^{39}$. O símbolo unificado do $V$-Label em todos esses países é muito semelhante ao proposto neste estudo, com o fundo amarelo e os dizeres "European Vegetarian Union" e "Vegetarian", como pode ser visto a seguir:

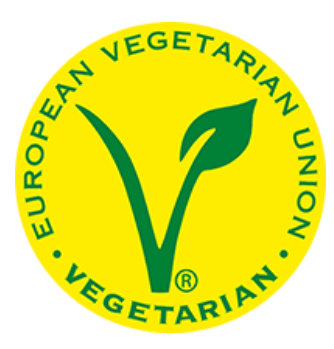

No Reino Unido não existe nenhuma lei oficial que regulamente a rotulagem de alimentos vegetarianos. Entretanto, a Food Standarts Agency, que é um órgão governamental, oferece um guia oficial para as empresas e organizações que queiram rotular os alimentos como vegetarianos ou veganos. O guia apresenta as definições das formas de dieta, assim como as sanções cabíveis em caso de erro de informação no rótulo e legislações complementares e análogas ${ }^{40}$.

Em uma publicação de 2014, chamada Food Atlas, organizada pela Heinrich Böll Foundation e pela Friends Of The Earth Europe, verificou-se que na Índia 31\% da população se declara vegetariana ${ }^{41}$, outras pesquisas apontam que mais da metade da população indiana

\footnotetext{
${ }^{39}$ Disponível em: <http://www.euroveg.eu/> e <http://www.v-label.info/>. Acesso em: 02 jun. 2016.

${ }^{40}$ Disponível em: <https://www.food.gov.uk/northern-ireland/niregulation/niguidancenotes/veg-term-guidance>. Acesso em: 02 jun. 2016.

${ }^{41}$ Disponível em: 〈https://www.foeeurope.org/sites/default/files/publications/foee_hbf_meatatlas_jan2014.pdf〉, p.57. Acesso em: 02 jun. 2016. 


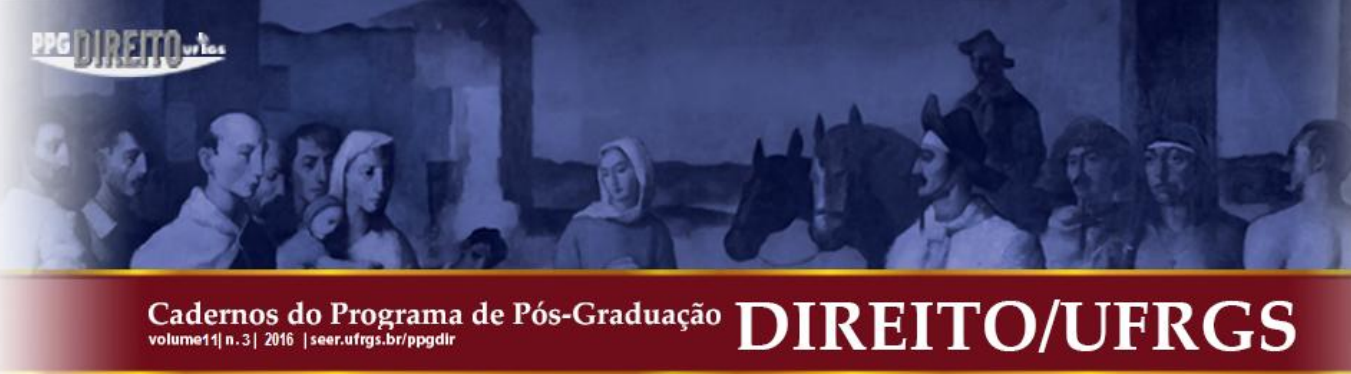

é, na prática, vegetariana. Por isso a Índia desde 2011 é o único país no mundo que regulamenta de maneira expressa e específica a rotulagem de alimentos vegetarianos.

A regulamentação do Ministry of Health and Family Welfare determina que todos os pacotes de alimentos vegetarianos devem notificar o consumidor através de um círculo verde dentro de um quadrado de borda verde e fundo branco, com o dobro do diâmetro do círculo ${ }^{42}$. Também é necessário o aviso para alimentos não vegetarianos, neste caso símbolo é na cor marrom em vez da cor verde, como pode ser visto na imagem a seguir:

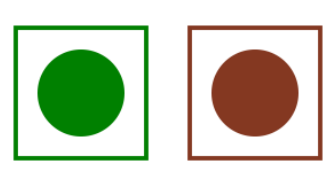

As sanções para a desobediência à Lei de Rotulagem indiana são severas. Em 2011 um fabricante de produtos alimentícios foi preso por seis meses por não ter imprimido o rótulo com as informações obrigatórias, inclusive o selo vegetariano ${ }^{43}$.

\section{PROPOSIÇÃO DE REGULAMENTAÇÃO PARA A ROTULAGEM DE PRODUTOS VEGETARIANOS}

A fim de se formar uma proposição mais acurada para a rotulagem de alimentos vegetarianos é necessária a inserção dos consumidores desta categoria de produtos na discussão social e jurídica que vem sendo desenvolvida.

Na pesquisa divulgada pelo IBOPE no dia $1^{\circ}$ de outubro de 2012 (Dia Mundial do Vegetariano) foi apresentada a estimativa de que 15,2 milhões de pessoas no Brasil eram

\footnotetext{
${ }^{42}$ MINISTRY OF HEALTH AND FAMILY WELFARE (Food Safety and Standards Authority of India) Notification: [...] 4. (iii) Every package of Vegetarian Food shall bear a declaration to this effect by a symbol and colour code as stipulated below for this purpose to indicate that the product is Vegetarian Food. The symbol shall consist of a green colour filled circle, having a diameter not less than the minimum size specified in the Table below, inside the square with green outline having size double the diameter of the circle, as indicated below. Disponível em:

<http://www.fssai.gov.in/Portals/0/Pdf/Food\%20Safety\%20and\%20standards\%20(Packaging\%20and\%20Labell ing)\%20regulation,\%202011.pdf>, p. 35. Acesso em: 02 jun. 2016.

${ }^{43}$ Disponível em: <http://www.thehindu.com/todays-paper/tp-national/tp-tamilnadu/6-months-imprisonment-topapad-maker-sellers/article2593551.ece>. Acesso em: 02 jun. 2016.
} 


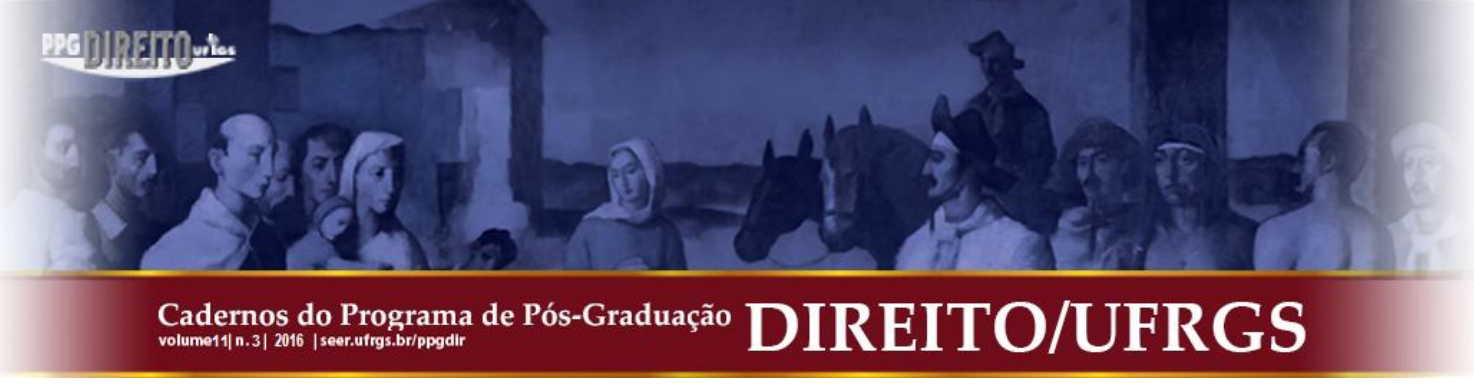

adeptas a dietas vegetarianas, o que significa dizer que $8 \%$ da população nacional se declarava vegetariana ${ }^{44}$.

Ao se fazer a comparação com dados levantados no tópico anterior, é possível perceber que o número de pessoas que se declaram vegetarianas é substancialmente maior que aquelas que possuem doença celíaca ou algum tipo de alergia alimentar (exceção feita à lactose). Apesar da óbvia diferença motivacional entre a questão do controle de doenças e da aderência a um estilo de vida - que eventualmente pode ser, também, por motivos de saúde -, o dever do Direito é a garantia da liberdade de escolha e do direito à informação para o consumidor. Portanto, existe uma grande porcentagem da população nacional inserida em um mercado de alimentos que ainda se encontra sem a proteção jurídica necessária, evidenciando uma vulnerabilidade especial de um determinado grupo de consumidores na relação de consumo.

Apesar da evolução nos últimos anos na garantia do direito básico do consumidor à informação, a possível regulamentação da rotulagem de alimentos no ordenamento jurídico brasileiro não é apta a proteger efetivamente o consumidor vegetariano por não garantir um conjunto de informações que são essenciais à escolha do produto. Nem mesmo a RDC dos alimentos que provocam alergias ou o Projeto de Lei da rotulagem de alimentos contendo lactose conseguem preencher essa lacuna, isso porque não tratam especificamente de alimentos como carne vermelha, frango e seus derivados, cuja informação sobre sua presença ou não em um produto é característica essencial para o consumidor vegetariano.

Muitos ingredientes e aditivos alimentares ${ }^{45}$ de origem animal são desconhecidos do consumidor que, por sua vez, não possui a obrigação de dominar o vocabulário nutricional, da indústria alimentícia ou até mesmo o vocabulário científico. Entre eles estão: o ácido esteárico, presente em gomas de mascar, retirados de gordura de vacas e ovelhas; a albumina, retirada de sangue, ovos, leite e alguns tipos de tecido de animais, utilizado em biscoitos,

44 Disponível em: <http://www.ibope.com.br/pt-br/noticias/paginas/dia-mundial-do-vegetarianismo-8-dapopulacao-brasileira-afirma-ser-adepta-ao-estilo.aspx>. Acesso em: 02 jun. 2016.

45 Portaria no 540 - Secretaria de Vigilância Sanitária/ Ministério da Saúde, de 27 de outubro de 1997. 1Definições: 1.1 - Ingrediente: é qualquer substância, incluídos os aditivos alimentares, empregada na fabricação ou preparação de um alimento e que permanece no produto final, ainda que de forma modificada. 1.2 - Aditivo Alimentar: é qualquer ingrediente adicionado intencionalmente aos alimentos, sem propósito de nutrir, com o objetivo de modificar as características físicas, químicas, biológicas ou sensoriais, durante a fabricação, processamento, preparação, tratamento, embalagem, acondicionamento, armazenagem, transporte ou

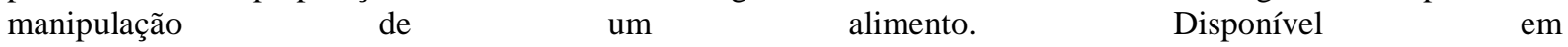
<http://portal.anvisa.gov.br/wps/wcm/connect/d1b6da0047457b4d880fdc3fbc4c6735/PORTARIA_540_1997.pd f?MOD=AJPERES $>$. Acesso em: 11 nov. 2015. 
bolos e outros tipos de comida; ácidos graxos naturais, produzidos a partir de sebo bovino; ácido lático, proveniente de sangue e tecido muscular animal, utilizado para bebidas fermentadas como a cerveja ou para alimentos em conserva; corante carmim ou ácido carmínico, proveniente do esmagamento da fêmea do inseto cochonilha, utilizado como corante artificial para alimentos sabor morango ou frutas vermelhas; gelatina, feita a partir do cozimento de ossos e ligamentos bovinos, vendida em pó ou contida nos ingredientes de alguns itens alimentícios; glicerina, potencialmente sintetizado a partir de gordura animal, dentre outros ${ }^{46}$.

Existe, portanto, uma necessidade latente de proteção do consumidor vegetariano, principalmente em relação a tutela daquilo que está previsto na Lei Federal no 8078/90: seu direito à informação e direito de escolha (art. $6^{\circ}$, II e III, respectivamente) e, além disso, a garantia do princípio da transparência e harmonia das relações de consumo (art. $4^{\circ}$, caput). Esta necessidade pode ser satisfeita mediante a regulamentação da rotulagem de alimentos vegetarianos, através de Lei específica que satisfaça a demanda de consumidores vegetarianos por informação, com base na Política Nacional das Relações de Consumo (art. $4^{\circ}$, CDC), que garante a proteção efetiva do consumidor pelo Estado através de iniciativa direta ${ }^{47}$.

No Estado de São Paulo, houve um movimento em direção à informação nos rótulos dos produtos que utilizem animais em sua composição, que foi o Projeto de Lei Estadual $n^{\circ}$ 479 de 2009, que fora aprovado na Assembleia Legislativa, porém posteriormente vetado pelo governador Geraldo Alckmin em 2013.

O referido texto legislativo resguardava a informação para produtos comercializados que contivessem componentes de origem animal ou fossem elaborados por métodos que utilizassem animais ${ }^{48}$. Em seu rótulo, o alimento deveria conter, dependendo do caso, uma das expressões "produto de origem animal", "componente do produto de origem animal", "produto testado em animal", "componente do produto testado em animal", "produto

\footnotetext{
${ }^{46}$ A PETA (People for the Ethical Treatment of Animals) é uma organização mundialmente conhecida, criada para a defesa dos animais. Lista completa, em inglês. Disponível em: <http://www.peta.org/living/beauty/animal-ingredients-list/>. Acesso em: 02 jun. 2016.

${ }^{47}$ Art. $4^{\circ}$. A Política Nacional das Relações de Consumo tem por objetivo o atendimento das necessidades dos consumidores, o respeito à sua dignidade, saúde e segurança, a proteção de seus interesses econômicos, a melhoria da sua qualidade de vida, bem como a transparência e harmonia das relações de consumo, atendidos os seguintes princípios: II - ação governamental no sentido de proteger efetivamente o consumidor: a) por iniciativa direta.

${ }^{48}$ Art. $1^{\circ}$. Na comercialização de qualquer produto que contenha animal, componente animal ou que tenha sido elaborado através de método que utilize animal, o consumidor deverá ser informado destas circunstâncias. Disponível em: <http://www.al.sp.gov.br/propositura/?id=874931>. Acesso em: 02 jun. 2016.
} 


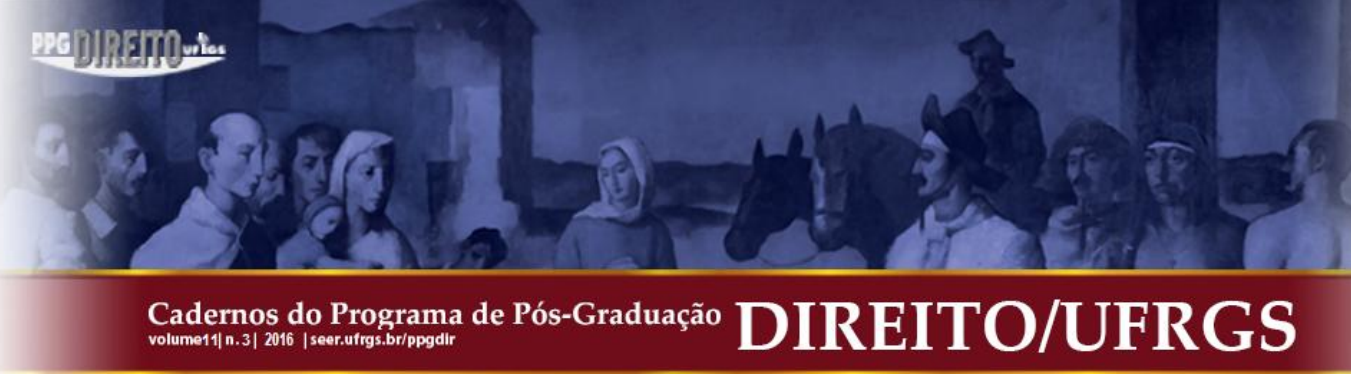

produzido a partir de teste em animal" ou "componente do produto produzido a partir do teste em animal", para qualquer produto embalado ou vendido a granel ou in natura ${ }^{49}$.

A proposta falha pela falta de praticidade para o fornecedor, dado o vasto rol categorias cujo alimento poderia se encontrar. Neste caso o legislador poderia ter simplificado a questão da informação utilizando-se da rotulagem vegana, tendo em vista que os adeptos desta dieta são aqueles que não consomem alimentos de origem animal ou qualquer produto que envolva sofrimento animal em alguma de suas etapas de produção. Entretanto essa ressalva não justifica o veto por parte do Poder Executivo.

A Sociedade Vegetariana Brasileira (SVB), uma sociedade civil de Direito Privado, sem fins lucrativos, com sede em Florianópolis, é um dos grupos mais ativistas na causa vegetariana no Brasil. A SVB oferece o chamado "selo vegano" para fornecedores que queiram se cadastrar, mediante pagamento de taxa, para possuir em seus produtos um selo certificando ao consumidor que se trata de fato de um bem de consumo que não possui componentes animais ou que não fora testado em animais em nenhuma etapa de sua produção ${ }^{50}$. Este tipo de rotulagem, apesar de ser uma iniciativa interessante, está longe de ser suficiente para atender a demanda, pois além de não atingir o objetivo jurídico da proteção do consumidor pelo Estado ela não gera obrigação para o fornecedor.

Sendo assim, para atender a demanda social de uma forma satisfatória, respeitando os direitos e princípios estabelecidos pelo Código de Defesa do Consumidor, é necessária uma proposta de rotulagem de produtos vegetarianos que resguardem o consumidor e ao mesmo tempo seja prática e acessível para o fornecedor.

Portanto, propõe-se a rotulagem de alimentos vegetarianos através de um símbolo composto da letra $\mathrm{V}$, preferencialmente na cor verde, com o fundo branco, ou ainda de outra forma que fique destacada, com uma folha que sai da letra, como se dela fosse parte conforme vista em imagem a seguir - uma vez que esta é uma simbologia que os próprios vegetarianos utilizam para identificação.

\footnotetext{
${ }^{49}$ Art. $2^{\circ}$. Tanto nos produtos embalados como nos vendidos a granel ou in natura, o rótulo da embalagem ou do recipiente em que estão contidos deverá constar, em destaque, no painel principal, uma das seguintes expressões, dependendo do caso: "produto de origem animal" ou "componente do produto de origem animal" ou "produto testado em animal" ou "componente do produto testado em animal" ou "produto produzido a partir de teste em animal" ou "componente do produto produzido a partir de teste em animal".

${ }^{50}$ Disponível em: <http://www.selovegano.com.br/>. Acesso em: 02 jun. 2016.
} 


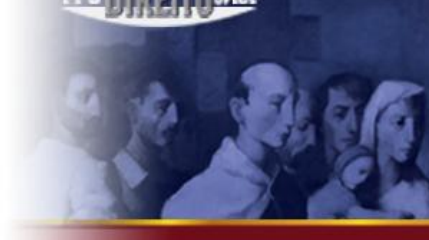

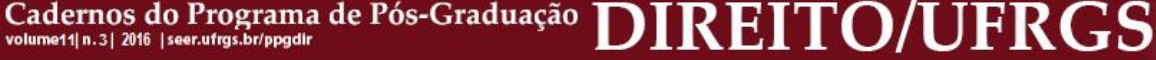

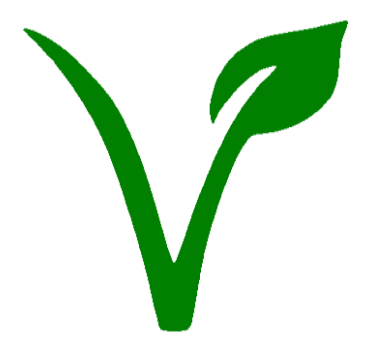

O tamanho carece de regulamentação, mas pode ser estabelecido de forma análoga à simbologia dos alimentos transgênicos, ocupando no mínimo $0,4 \%$ da área do painel principal do rótulo.

O artigo 31 da Lei Federal $n^{\circ}$ 8.078/90 serve de justificativa e de orientação para a logomarca, tendo em vista que a rotulagem apresentará o produto com a informação correta, clara, precisa e ostensiva. A rotulagem deve estar vinculada, em princípio, àquilo que é ingerido pelo consumidor na forma de alimento, já que o artigo 31 traz como elemento de apresentação de produtos, a informação sobre sua origem - no caso origem vegetal ou animal - não se atendo aos seus meios de produção, a não ser que apresentem algum risco à saúde e à segurança do consumidor. As informações acerca de testes em animais ou qualquer outro tipo utilização animal durante o processo de manufatura de produtos são propostas alheias a esta, demandando estudos mais aprofundados do tema.

\section{CONSIDERAÇÕES FINAIS}

O Direito é fundamental na sociedade, entre outras coisas, por preencher lacunas e equilibrar a balança social de forma que as pessoas possam usufruir de relações justas. No Direito das Relações de Consumo essa balança é essencialmente desequilibrada, pois a vulnerabilidade está impregnada no próprio conceito de consumidor.

As leis consumeristas devem fazer com que essa vulnerabilidade se transforme em direitos e garantias, levando o consumidor para uma posição de igualdade em relação ao fornecedor na relação de consumo. Neste sentido, muitas leis surgiram para remediar esse desequilíbrio - inclusive o próprio Código de Defesa do Consumidor. Ocorre que, em alguns casos, determinados grupos de pessoas possuem uma demanda específica de consumo, especialmente em relação a bens de consumo alimentícios, por diversos motivos. 


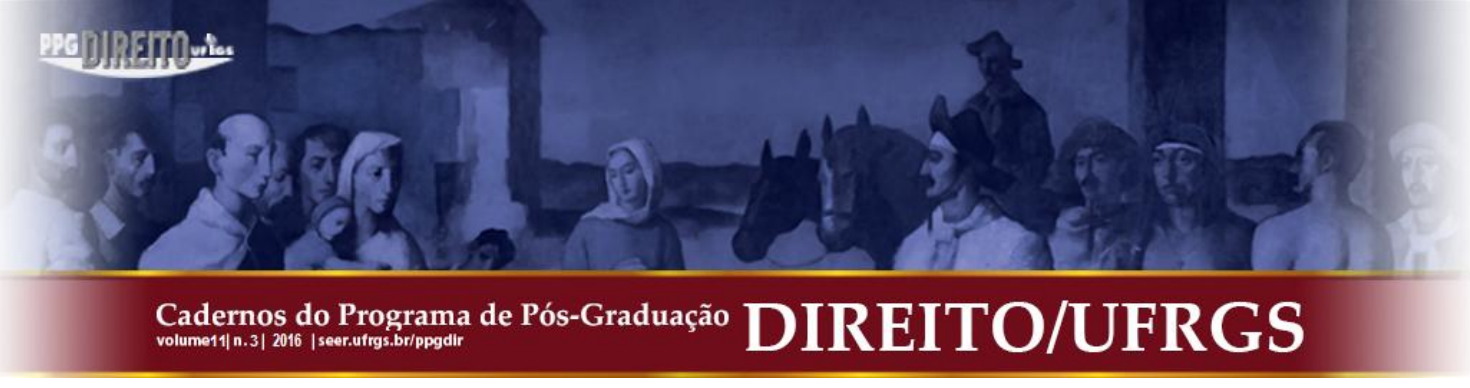

Entre essas demandas estão os celíacos (que não podem comer glúten), os intolerantes e alérgicos à lactose (açúcar presente em laticínios), aqueles que possuem outros tipos de alergia alimentares e os vegetarianos. Os que não podem ingerir glúten já estão resguardados pela Lei Federal no 10.674/03; para aqueles que possuem alergias alimentares a RDC $\mathrm{n}^{\mathrm{o}} 26 \mathrm{de}$ 2015 da ANVISA já está em vigor, contando o prazo de um ano para os fornecedores se

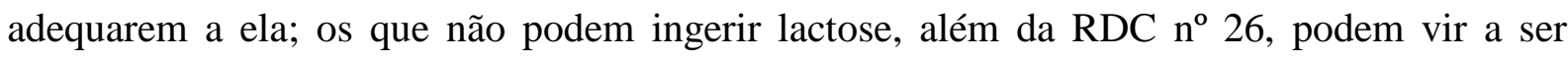
protegidos PL 8.194 de 2014, que prevê a rotulagem de produtos que contém lactose tal como acontece com o glúten.

Porém o consumidor vegetariano ainda não possui nenhuma garantia de reconhecimento de seu direito à informação por parte do Estado. Apesar de aproximadamente 15 milhões de brasileiros se identificarem como vegetarianos de acordo com pesquisa realizada pelo IBOPE em 2012, não existe previsão legal que garanta o seu direito a informação em relação a ingredientes que - por qualquer que seja o motivo - não façam parte da sua dieta.

É fundamental, portanto, a discussão sobre o assunto para que os legisladores escutem a demanda crescente por proteção ao consumidor vegetariano, uma vez que atender as necessidades dos consumidores, melhorando sua qualidade de vida e harmonia e transparência nas relações de consumo é política do Estado brasileiro, como explicitado na Política Nacional das Relações de Consumo (art. $4^{\circ}$, caput, CDC), Isso é concretizado quando o consumidor consegue exercer o seu direito de escolha a partir da garantia ao direito à informação (art. $6^{\circ}, \mathrm{CDC}$ ).

Para tanto, o Estado através de suas instituições deve regulamentar em forma de Lei podendo tomar como exemplo a Lei Federal n 11.105/05 (Lei dos Transgênicos) e a Lei Federal n 10.674/03 (que regulamenta informações sobre o glúten no rótulo dos alimentos) a utilização no rótulo dos alimentos vegetarianos de uma marca de fácil identificação para o seu público consumidor, como por exemplo, a letra "V" estilizada e de cor verde proposta neste texto. 


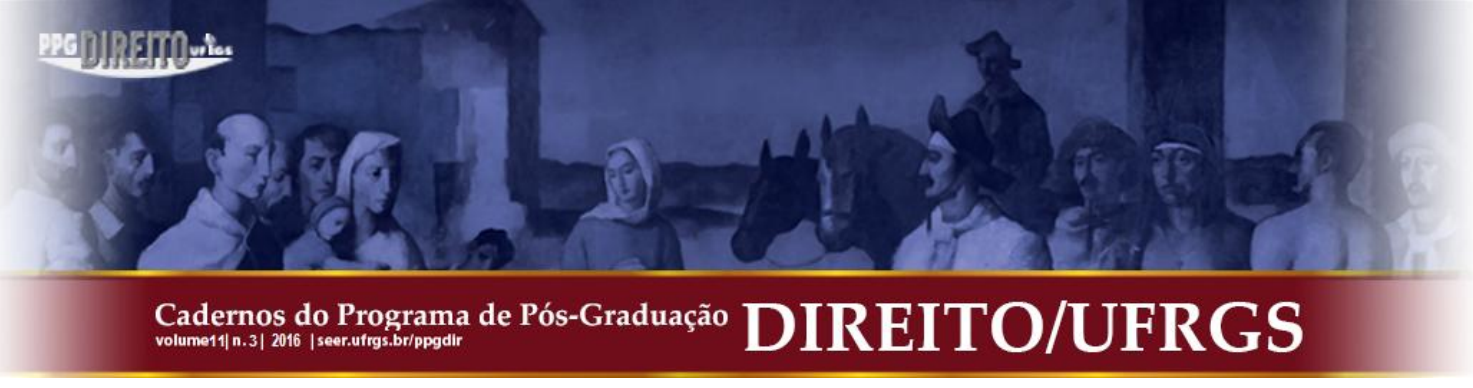

\section{REFERÊNCIAS}

ALERGIA Alimentar. Associação Brasileira de Alergia e Imunologia. São Paulo, 06 jul. 2009. Disponível em: <http://www.asbai.org.br/secao.asp?s=81\&id=306>. Acesso em: 02 jun. 2016.

ALVES, Fabrício Germano, Proteção constitucional do consumidor no âmbito da regulação publicitária. 1. ed. Natal: Espaço Internacional do Livro, 2013.

ANALÍTICOS, Limites. Doença celíaca: contributo da análise laboratorial para uma dieta isenta de glúten. especial 2.

ANIMAL Ingredients List. Peta. Disponível em: <http://www.peta.org/living/beauty/animalingredients-list/>. Acesso em: 02 jun. 2016.

BRASIL. Decreto-Lei $n^{o}$ 986, de 21 de outubro de 1969. Institui normas básicas sobre alimentos.

Lei Federal $n^{o}$ 8.078, de 11 de setembro de 1990. Dispõe sobre a proteção do consumidor e dá outras providências.

Lei Federal $n^{\circ}$ 9.782, de 26 de janeiro de 1999. Define o Sistema Nacional de Vigilância Sanitária, cria a Agência Nacional de Vigilância Sanitária, e dá outras providências.

Lei Federal $n^{\circ} 10.674$, de 16 de maio de 2003. Obriga a que os produtos alimentícios comercializados informem sobre a presença de glúten, como medida preventiva e de controle da doença celíaca.

Lei Federal $n^{\circ} 11.105$, de 24 de março de 2005. Regulamenta os incisos II, IV e V do $\S 1^{\underline{0}}$ do art. 225 da Constituição Federal, estabelece normas de segurança e mecanismos de fiscalização de atividades que envolvam organismos geneticamente modificados - OGM e seus derivados, cria o Conselho Nacional de Biossegurança - CNBS, reestrutura a Comissão Técnica Nacional de Biossegurança - CTNBio, dispõe sobre a Política Nacional de Biossegurança - PNB, revoga a Lei $n^{0}$ 8.974, de 5 de janeiro de 1995, e a Medida Provisória $\mathrm{n}^{\mathrm{o}} 2.191-9$, de 23 de agosto de 2001 , e os arts. $5^{-}, 6^{\circ}, 7^{\underline{o}}, 8^{\circ}, 9^{-0}, 10$ e 16 da Lei $\mathrm{n}^{\mathrm{o}} 10.814$, de 15 de dezembro de 2003, e dá outras providências. 


\section{5

. Portaria $n^{o} 2658$ do Ministério da Justiça, de 22 de dezembro de 2003. Disponível

em: <http://agrobiobrasil.org.br/wp-content/uploads/2014/01/Portaria-MJ-2658-de-2003Regulamenta-uso-do-s\%C3\%ADmbolo-dos-transg\%C3\%AAnicos.pdf >. Acesso em: 02 jun. 2016.

Portaria $n^{\circ} 540$ da Secretaria de Vigilância Sanitária/Ministério da Saúde, de 27 de outubro de $1997 . \quad$ Disponível em: <http://portal.anvisa.gov.br/wps/wcm/connect/d1b6da0047457b4d880fdc3fbc4c6735/PORTA RIA_540_1997.pdf?MOD=AJPERES >. Acesso em: 11 nov. 2015.

Projeto de Lei Federal $n^{o}$ 8.194, de 03 de dezembro de 2014. Acrescenta art. 19-A ao Decreto-Lei no 986, de 21 de outubro de 1969, que "institui normas básicas sobre alimentos", para dispor sobre a rotulagem de alimentos que contenham lactose. Disponível em: $<$ http://www.camara.gov.br/proposicoesWeb/prop_mostrarintegra?codteor=1292258\&filena me=PL+8194/2014>. Acesso em: 02 jun. 2016.

Resolução de Diretoria Colegiada da Agência Nacional de Vigilância Sanitária $n^{\circ}$

360, de 23 de dezembro de 2003. Disponível em: <http://portal.anvisa.gov.br/documents/33880/2568070/res0360_23_12_2003.pdf/5d4fc7139c66-4512-b3c1-afee57e7d9bc>. Acesso em 02 jun. 2016.

Resolução de Diretoria Colegiada da Agência Nacional de Vigilância Sanitária nº 26, de 02 de julho de 2015. Dispõe sobre os requisitos para rotulagem obrigatória dos principais alimentos que causam alergias alimentares. Disponível em: <http://www.abic.com.br/publique/media/rdc26.pdf>. Acesso em: 02 jun. 2016.

CERTIFICAÇÃO Selo Vegano. Sociedade Vegetariana Brasileira. São Paulo. Disponível em: <http://www.selovegano.com.br/>. Acesso em: 02 jun. 2016.

CONAR. Código Brasileiro de Autorregulamentação Publicitária. Disponível em: <http://www.conar.org.br/codigo/codigo.php>. Acesso em: 02 jun. 2016.

CONHEÇA a doença celíaca em 3 cliques. Federação Nacional das Associações de Celíacos do Brasil. Disponível em: 〈http://www.fenacelbra.com.br/fenacelbra/>._Acesso em: 02 jun. 2016.

DIA Mundial do Vegetarianismo: $8 \%$ da população brasileira afirma ser adepta do estilo. IBOPE, 01 out. 2012. Disponível em: <http://www.ibope.com.br/pt-br/noticias/paginas/dia- 


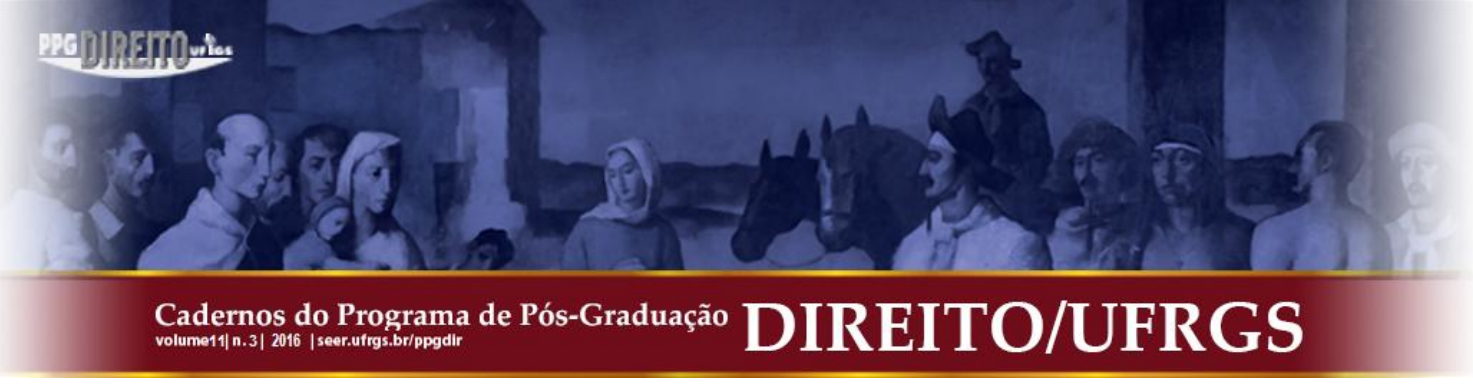

mundial-do-vegetarianismo-8-da-populacao-brasileira-afirma-ser-adepta-ao-estilo.aspx>. Acesso em: 02 jun. 2016.

EUROPEAN Vegetarian Union Label. Disponível em: 〈http://www.euroveg.eu/> e em: $\leq$ http://v-label.eu/>.Acesso em: 02 jun. 2016.

FELIPE, Sônia T. Antropocentrismo, sencientismo e biocentrismo: perspectivas éticas abolicionistas, bem-estaristas e conservadoras e o estatuto de animais não-humanos. Revista Páginas de Filosofia. v. 1, n. 1, jan./jul. 2009, p. 5. Disponível em: <https://www.metodista.br/revistas/revistas-ims/index.php/PF/article/viewFile/864/1168>.

Acesso em: 02 jun. 2016.

FRIENDS OF THE EARTH EUROPE. Meat Atlas: Facts and figures about the animals we eat. Jan. 2014. Disponível em: <https://www.foeeurope.org/sites/default/files/publications/foee_hbf_meatatlas_jan2014.pdf> . Acesso em: 02 jun. 2015.

LIVESTOCK a major threat to environment: Remedies urgently needed. Food and Agriculture Organization of the United Nations, Roma, 29 nov. 2006. Disponível em: <http://www.fao.org/newsroom/en/news/2006/1000448/index.html>. Acesso em: 02 jun. 2016.

GRINOVER, Ada Pellegrini et al. Código Brasileiro de Defesa do Consumidor: comentado pelos autores do anteprojeto. 8. ed. Rio de Janeiro: Forense Universitária, 2004.

ÍNDIA. Ministry of Health and Family Welfare. Food Safety and Standards (Packing and Labeling) Regulations, 2011. Disponível em: $<$ http://www.fssai.gov.in/Portals/0/Pdf/Food\%20Safety\%20and\%20standards\%20(Packaging \%20and\%20Labelling)\%20regulation,\%202011.pdf>. Acesso em: 02 jun. 2016.

MATOSO, Vanessa de Azevedo. A publicidade de alimentos: uma análise acerca da informação prestada ao consumidor. 2015. Trabalho de Conclusão de Curso (Bacharelado em Direito) - Centro de Ciências Sociais Aplicadas, Universidade Federal do Rio Grande do Norte.

NUNES, Rizzatto. Curso de Direito do Consumidor. 6. ed. Saraiva: São Paulo, 2011. 


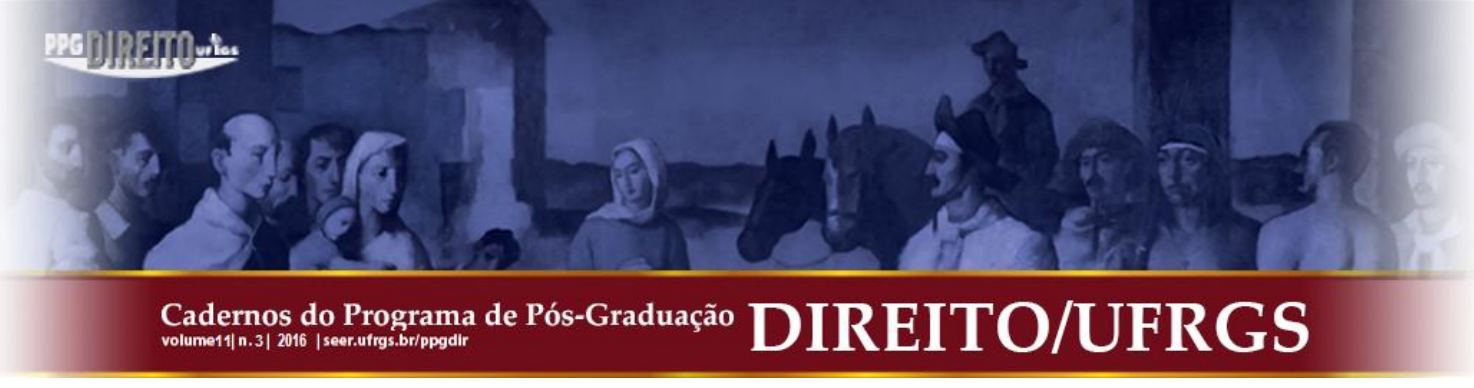

SÃO PAULO. Projeto de Lei Estadual no 479, de 17 de junho de 2009. Regulamenta o direito à informação, assegurado pelo Código de Defesa do Consumidor (Lei no 8.078, de 11 de setembro de 1990), no âmbito do Estado de São Paulo, relativamente aos rótulos dos produtos e componentes dos produtos que contenham animal ou que tenham sido produzidos a partir de métodos que utilizem animal, sem prejuízo do cumprimento das demais normas aplicáveis. Disponível em: <http://www.al.sp.gov.br/propositura/?id=874931〉. Acesso em: 02 jun. 2016.

SLYWITCH, Eric. Guia alimentar de dietas vegetarianas para adultos. São Paulo: SVB, 2012.

Virei vegetariano, e agora? 1. ed. São Paulo: Alaúde, 2010.

TARTUCE, Flávio; NEVES, Daniel Amorim Assumpção. Manual de direito do consumidor: direito material e processual. 3. ed. Rio de Janeiro: Forense: São Paulo: Método, 2014.

THE HINDU TIMES. 6 months imprisonment to papad makers, sellers. Arquivo da Web. Disponível em: <http://www.thehindu.com/todays-paper/tp-national/tp-tamilnadu/6-monthsimprisonment-to-papad-maker-sellers/article2593551.ece>. Acesso em: 02 jun. 2016.

USE of Terms "Vegetarian" and "Vegan" in Food Labeling: Guidance. Food Standads Agency Nothern Ireland.. Disponível em: <http://webarchive.nationalarchives.gov.uk/+/http://www.food.gov.uk/northernireland/niregulation/niguidancenotes/veg-term-guidance>.

Acesso em: 02 jun. 2016.

VARELLA, Dráuzio. Intolerância à Lactose. Arquivo da Web. Disponível em: <http://drauziovarella.com.br/letras/l/intolerancia-a-lactose/>.Acesso em: 02 jun. 2016.

Submissão: 21/06/2016

Aceito para Publicação: 01/02/2017 


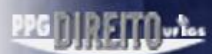

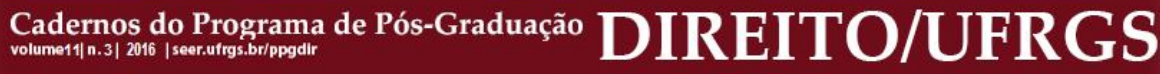

